\title{
Green Marketing and the Green Product Buying Behaviors of Consumers: An Application in Atatuirk University
}

\author{
M. Serdar Erciş, Atatürk University, Turkey \\ Arzu Kalafat Çat, Atatürk University, Turkey
}

\begin{abstract}
Green marketing is part of the understanding of environmentally sensitive business administration. Businesses need to make all production process green in order to demonstrate their environmental sensitivity. In other words, going green requires a holistic approach. In terms of environmentalism, it is extremely important for business owners and managers to be environmentally conscious and make other workers so, to choose raw material with the least harm to the environment, to improve the processes of production in order to reduce waste amount, to recycle waste, to collect unrecyclable waste and destroy it with the least harm to the environment. Reducing the amount of packaging, choosing recyclable decomposable material for packaging and encouraging the collecting of packaging waste are energy elements of distribution and promotion. Businesses have to become as sensitive as individuals towards the natural environment in order to survive themselves. In this study, the relationships between the social-demographic characteristics of consumers and consumers' green purchasing behaviour have been examined. In the research part of the study, a research was made on the fourth classs tudents of Atatürk University, Faculty of Communication. The research is madewith a survey which includes questions about student's environmental experience, their attitude about environment and their thought about environmental issues. Research realized on 200 samples.
\end{abstract}

Keywords: Greenmarketing, greenproduct 


\section{Introduction}

Today consumers' needs and demands are changing rapidly and businesses work to improve their understanding of administration, areas of activity and strategies of marketing in order to keep up with the many changes taking place globally. While producers' decisions take commercial worries, competition and consumer demands into account and consumers' decisions are directed by buying behaviors, satisfaction of needs and many psychological factors, both producers and consumers are influenced in decision-making by their relationship with the external milieu. Thus the cultural and social milieu, the economic, political and legal milieu, the demographic and technological milieu and the natural milieu directly shape the decision-making processes of businesses and consumers. Two of the most important external milieu factors which affect businesses and consumers are the natural balance of the world and the elements of ecology. Ecology and natural balance have for so long not come into prominence due to problems of individual awareness as well as problems of society and the country and their importance has begun to be understood only recently. Businesses now consider these issues in their strategies of production and design of products and consumers pay importance to whether a certain product is harmful to the environment. This interaction between producers and consumers has resulted in the formation of a clearer understanding of environmental awareness and protection of natural balance on both sides. Environmental awareness has taken root and protection of nature has become much more important around the globe. These developments have now led to the establishment of environmental NGOs and helped place the natural environment among the criteria for international quality standards and legal regulations. These developments have also affected marketing activities substantially and thus an understanding under the name of environmentalist marketing which takes ecological factors into account in every step of the design of marketing activities has developed.

Accordingly, this study aims to examine the developments regarding protection of the natural environment, social marketing and the approach of environmentalist marketing andto question the existence of relations between the environmentalist attitudes of consumers and their buying behaviors. The study first brings environmentalism and social marketing under scrutiny and then defines the approach of environmentalist marketing on which the effects of the two former phenomena are observed. 


\section{Green Marketing}

Green marketing has been given different names by marketing scientists and been named also as social marketing, ecological marketing, environmental marketing and sustainable marketing (Soonthonsmai, 2001: 18; Chamorro and Banegil, 2006: 11; Chamorro et al., 2007). The definitions of green marketing and environmentalist marketing are still vague and have only rarely been made in a comprehensible and accurate manner. Green marketing was for the first time discussed and defined at a seminar on ecological marketing organized by the American Marketing Association in 1975. According to that definition, ecological marketing is studies on the positive and negative effects of marketing activities on environmental pollution, energy consumption and consumption of other sources (Erbaşlar, 2007:25). Peattie (2001) defines green marketing as the attempt to decrease the negative social and environmental effects of products and production systems, and as marketing activities which support products/services with bad effects less. According to a definition from the perspective of consumers, green marketing is a guiding term to describe the needs and desires of those segments of consumers who are environmentally concerned. Pride and Ferrell (1993) name as green marketing the efforts of organizations to design, promote, price and distribute environmentally safe products (Grove, 1996: 56; Jain and Kaur, 2004: 188) and Polonsky (1994) describes it as designing all activities to allow for and facilitate any exchange which tends to satisfy people's needs and desires with minimal harm to the environment (Jain and Kaur, 2004: 188). In short, green marketing consists of marketing activities which involve the production, pricing, distribution and promotion of nature friendly products that help businesses reach its goals while at the same time meeting consumers' needs and desires and which continue after a product starts being used.

\section{Green Products}

A green product is one which does not pollute the world or exhaust natural sources and can be recycled or maintain its value (Shamdasani et al., 1993: 488). It is expected not to (Moisander, 2007: 405):

- Threaten the health of people or animals.

- Cause damage to the environment during manufacture, use or removal.

- Consume a disproportionate amount of energy or other sources during manufacture, use or removal.

- Cause unnecessary waste due to excessive packaging or to a short useful life. 
- Involve the unnecessary use of or cruelty to animals.

- Use materials from threatened species or environments.

No consumer product has zero effects on the environment and a green product is defined in the business world as one which aims to grow or protect the natural environment by conserving energy and other sources and/or by reducing and/or eliminating pollution, waste and toxic material (Ottman, 2006: 24).

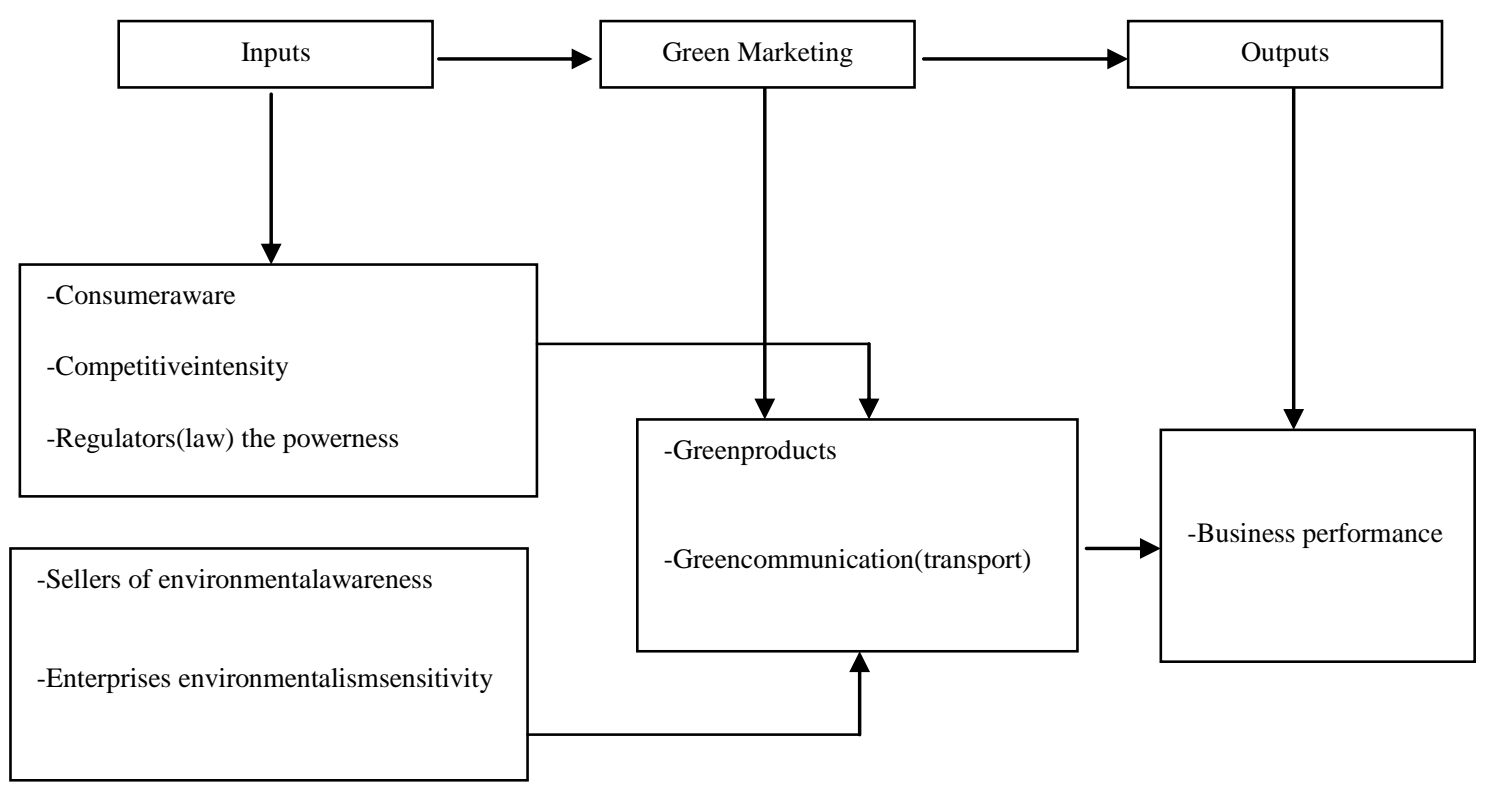

Shape 1. Green marketing inputs and outputs

As seen in the figure, the environmental sensitivity of consumers, the level of competition in the relevant industry and the power of environmentalist laws combine with the environmental awareness of sellers and the environmental sensitivity of businesses and thus high levels of business performance are achieved. So, green marketing serves as a bridge among the factors mentioned and thus helps the process be completed.

\section{A Study on Consumers' Attitudes and Behaviors Regarding Green Marketing Practices}

Presented below are the results from the study on how the philosophy of green marketing is perceived by a group of consumers and by students who are candidates for nomination for administrator and what kinds of attitudes and behaviors they display towards green marketing practices. 


\section{The Purpose and Importance of the Study}

The purpose of this study is to demonstrate the levels of knowledge, approaches and levels of sensitivity of the students of the Atatürk University School of Communication concerning environmental issues and green marketing. Environmental issues are among the most important problems of our day. Businesses are viewed as the greatest causes of environmental issues due to their applications, processes of production, products and environmental wastes. In this regard, in order for environmental issues to be reduced to minimum, businesses should transform their processes of production to cause less environmental waste, design their products with an effort to reduce their effects on the environment, reduce environmental waste to minimum through recycling and process environmental waste for minimum damage to the environment, choose for packaging products decomposable material with the least environmental harm and reduce the amount of packaging used. Additionally, employing methods which save energy and give less harm to the environment in the processes of distribution and promotion is important in terms of achieving a sustainable economy and a sustainable business management. In this regard, it is important in terms of a sustainable business management to identify the levels of knowledge, attitudes, tendencies and thoughts regarding environment and green marketing of students who take an academic and professional interest in communication and are expected to be business managers in the future.

\section{The Method}

The study is going to identify the levels of knowledge, attitudes and thoughts of students concerning environment and green marketing. Therefore, a descriptive research model to provide a basis for future scientific study is seen as fit.

\section{The Universe and Sample of Research}

A questionnaire, with questions from studies on the environment (Demirbaş, 1999:35; Durali, 2002:30; Marangoz, 2003:44; Y1lmaz, 2003:51), is used in the collection of data. It consists of three parts. In the first part, there are demographic questions and questions relating to experiences about environment and green marketing. The majority of these questions elicit dichotomous answers (yes/no). There are 9 three-choice statements in the second part and they exhibit the attitudes of the students towards green marketing. The third part has 12 statements which display the thoughts of the students on the environment. The students are 
asked to choose one of the following options for each sentence: "I absolutely agree," "I agree," "I cannot decide," "I do not agree," "I absolutely do not agree." The scale was from 1 to 5 .

\section{The Analysis of Data}

The attitudes and thoughts of the students concerning the environment and green marketing are examined and the data are analyzedby SPSS package program in the computerized environment.

\section{The Findings of the Research}

Some demographic characteristics of the students according to the responses to the research questionnaire are shown in Table 1.

Table1: Demographic Features

\begin{tabular}{|c|c|c|c|}
\hline \multirow{3}{*}{ Gender } & & frequency & $\%$ \\
\hline & Female & 50 & 25 \\
\cline { 2 - 4 } & Male & 150 & 75 \\
\hline \multirow{3}{*}{$\begin{array}{c}\text { Average monthly } \\
\text { family income } \\
\text { (TL). }\end{array}$} & Total & 200 & 100 \\
\cline { 2 - 4 } & $0-750$ & 28 & 14 \\
\cline { 2 - 4 } & $751-1500$ & 50 & 25 \\
\cline { 2 - 4 } & $1501-2000$ & 42 & 21 \\
\cline { 2 - 4 } & $2001+$ & 80 & 100 \\
\hline
\end{tabular}

The students in the research are 50 women (25\%) and 150 men (75\%). 28 students (14\%) come from lower-income families, 50 students $(25 \%)$ from middle-income families, 42 students $(21 \%)$ from upper-middle income families, and 80 students (40\%) from upperincome families. 
Table.2. Experiences of Students about the Environment

\begin{tabular}{|l|c|c|c|c|}
\hline & \multicolumn{2}{|c|}{ Yes } & \multicolumn{2}{|c|}{ No } \\
\cline { 2 - 5 } & F & F & F \\
\hline Are you a member of any environmental NGO? & 32 & 20,6 & 123 & 79,4 \\
\hline $\begin{array}{l}\text { Is anyone in your family or anyone in your close circle } \\
\text { a member of any environmental NGO? }\end{array}$ & 71 & 45,8 & 84 & 54,2 \\
\hline $\begin{array}{l}\text { Did you take any theoretical course on the environment } \\
\text { during college education? }\end{array}$ & 22 & 14,2 & 133 & 85,8 \\
\hline $\begin{array}{l}\text { Did you or anybody in your family encounter an } \\
\text { environmental threat (flood, food poisoning, radiation } \\
\text { etc.)? }\end{array}$ & 56 & 36,1 & 99 & 63,9 \\
\hline $\begin{array}{l}\text { Did you ever purchase environmentally friendly } \\
\text { products? }\end{array}$ & 115 & 74,2 & 40 & 25,8 \\
\hline $\begin{array}{l}\text { Were you satisfied with the product or products which } \\
\text { you purchased? }\end{array}$ & 120 & 77,4 & 35 & 22,6 \\
\hline $\begin{array}{l}\text { Did you ever file a complaint against a product which } \\
\text { purchased to any organization for protecting consumers } \\
\text { due to the product's environmental threat? }\end{array}$ & 133 & 85,8 & 22 & 14,2 \\
\hline $\begin{array}{l}\text { To date purchased for a swag, the environmental threat } \\
\text { to an institution because of any complaint related to } \\
\text { consumer protection Have you been? }\end{array}$ & 14 & 9.0 & 141 & 91,0 \\
\hline $\begin{array}{l}\text { Was the subject of complaint satisfactorily solved by } \\
\text { the relevant departments? }\end{array}$ & 6 & 46,1 & 7 & 53,8 \\
\hline $\begin{array}{l}\text { Did you ever come across any efforts to promote green } \\
\text { products or green marketing? }\end{array}$ & 66 & 42,6 & 89 & 57,4 \\
\hline
\end{tabular}

$20.6 \%$ of the School of Communication students in the research are members of an environmental NGO. $45.8 \%$ of the students have someone in their family or someone in their close circle who is a member of an environmental NGO. $14.2 \%$ took a theoretical course on the environment during college education. $36.1 \%$ encountered an environmental threat themselves or have someone in their family who encountered an environmental threat. $74.2 \%$ purchased environmentally friendly products. $77.4 \%$ of those who purchased environmentally friendly products were satisfied with them. $85.5 \%$ are aware that environmentally friendly green products are sold in Turkey. $9 \%$ filed a complaint against a product which they purchased to an organization for protecting consumers due to the product's environmental threat. $46.1 \%$ of the complaints were satisfactorily addressed by the relevant departments. 42.6 came across efforts to promote green products and green marketing. 
Table 3. Environmental Reaction

\begin{tabular}{|c|c|c|c|c|c|c|}
\hline \multirow{3}{*}{$\begin{array}{l}\text { How would } \\
\text { you behave if } \\
\text { you found } \\
\text { out that a } \\
\text { product } \\
\text { which you } \\
\text { bought was } \\
\text { harmful to } \\
\text { the } \\
\text { environment? }\end{array}$} & $\begin{array}{c}\text { Purchasing } \\
\text { Leave }\end{array}$ & & $\begin{array}{c}\text { Less To } \\
\text { Buy }\end{array}$ & & $\begin{array}{l}\text { I Go The } \\
\text { Same Way }\end{array}$ & \\
\hline & $\mathrm{F}$ & $\%$ & $\mathrm{~F}$ & $\%$ & $\mathrm{~F}$ & $\%$ \\
\hline & 67 & 43,2 & 85 & 54,9 & 3 & 1,9 \\
\hline
\end{tabular}

$98 \%$ of the students expressed that they would react ("I will not buy it again." $43.2 \%$; "I will buy it less often." $54.9 \%$ ) if they found out that a product which they bought was harmful to the environment (Table 3). This result demonstrates the level of sensitivity of the students towards environmental issues.

Table 4. Environmental Attitudes of Students

\begin{tabular}{|l|l|l|l|l|l|l|}
\hline & \multicolumn{2}{|c|}{ Always } & \multicolumn{2}{c|}{ Sometimes } & \multicolumn{2}{c|}{ Never } \\
\hline & F & \multicolumn{1}{|c|}{ F } & \multicolumn{1}{|c|}{ F } & & \\
\hline I buy products with less packaging. & 17 & 11,0 & 105 & 67,7 & 33 & 21,3 \\
\hline $\begin{array}{l}\text { I prefer products with environmentally friendly } \\
\text { packaging (glass, paper etc.). }\end{array}$ & 62 & 40,0 & 89 & 57,4 & 4 & 2,6 \\
\hline $\begin{array}{l}\text { I keep domestic waste separately (paper, glass, } \\
\text { metal etc.). }\end{array}$ & 21 & 13,5 & 73 & 47,1 & 61 & 39,4 \\
\hline $\begin{array}{l}\text { I take products like newspaper and paper to } \\
\text { relevant organizations so that they can be reused. }\end{array}$ & 14 & 9,1 & 67 & 43,2 & 74 & 47,7 \\
\hline I buy recycled products. & 15 & 9,7 & 113 & 72,9 & 27 & 17,4 \\
\hline I use the recycling boxes around the city. & 28 & 18,1 & 86 & 55,5 & 41 & 26,5 \\
\hline $\begin{array}{l}\text { I warn people who pollute the environment } \\
\text { (throwing waste on the ground, spitting etc.). }\end{array}$ & 59 & 38,1 & 82 & 52,9 & 14 & 9,0 \\
\hline $\begin{array}{l}\text { I pay attention to energy consumption (turning off } \\
\text { unnecessary lamps, not using too much water etc.). }\end{array}$ & 113 & 72,9 & 36 & 23,2 & 6 & 3,9 \\
\hline I use the recycling boxes around the campus. & 32 & 20,6 & 74 & 47,8 & 49 & 31,6 \\
\hline
\end{tabular}


$11 \%$ of the students expressed that they "always" purchased products with less packaging while $67.7 \%$ expressed that they "sometimes" did. $40 \%$ stated that they "always" preferred products with environmentally friendly packaging while $57.4 \%$ stated that they "sometimes" did. $13.5 \%$ said that they "always" kept domestic waste separately while $47.1 \%$ said that they "sometimes" did. The rate of those who said that they "always" took products like newspaper and paper to relevant organizations so that they could be reused was $9.1 \%$ while the rate of those who said that they "sometimes" did was $43.2 \% .9 .7 \%$ said that they "always" bought recycled products while $72.9 \%$ said that they "sometimes" did. $18.1 \%$ said that they "always" used the recycling boxes around the city while $55.5 \%$ said that they "sometimes" did. The rate of those who said that they "always" warned people who polluted the environment was $38.1 \%$ while the rate of those who said that they "sometimes" did was $52.9 \%$. The rate of those who stated that they "always" paid attention to energy consumption was $72.9 \%$ while the rate of those who stated that they "sometimes" did was $23.2 \%$. Finally, $20.6 \%$ stated that they "always" used the recycling boxes around the campus while $47.8 \%$ stated that they "sometimes" did.

Table 5. Thoughts of Students Concerning the Environment

\begin{tabular}{|c|c|c|c|c|c|c|c|c|c|c|c|c|}
\hline \multirow[t]{2}{*}{ Opinions } & \multicolumn{2}{|c|}{1} & \multicolumn{2}{|c|}{2} & \multicolumn{2}{|c|}{3} & \multicolumn{2}{|c|}{4} & \multicolumn{2}{|c|}{5} & \multirow{2}{*}{$\begin{array}{c}\text { averag } \\
\mathrm{e}\end{array}$} & \multirow{2}{*}{$\begin{array}{c}\text { standard } \\
\text { deviatio } \\
n\end{array}$} \\
\hline & $\mathrm{F}$ & $\%$ & $\mathrm{~F}$ & $\%$ & $\mathrm{~F}$ & $\%$ & $\mathrm{~F}$ & $\%$ & $\mathrm{~F}$ & $\%$ & & \\
\hline $\begin{array}{l}\text { Progress is more important than } \\
\text { the environment for developing } \\
\text { countries like Turkey. }\end{array}$ & 20 & 12,9 & 42 & 27,1 & 21 & 13,5 & 50 & 32,3 & 22 & 14,2 & 3,07 & 1,29 \\
\hline $\begin{array}{l}\text { Making investments to solve } \\
\text { environmental issues is luxurious } \\
\text { for Turkey. }\end{array}$ & $\begin{array}{c}2 \\
1,3\end{array}$ & 13,8 & 20 & 12,9 & 22 & 14,2 & 59 & 38,1 & 52 & 33,5 & 3,89 & 1,05 \\
\hline $\begin{array}{l}\text { Increasing Turkey's production of } \\
\text { electricity is more important than } \\
\text { environmental pollution (in terms } \\
\text { of thermal reactors). }\end{array}$ & $\begin{array}{c}9 \\
5,8\end{array}$ & 11,0 & 36 & 23,2 & 25 & 16,1 & 48 & 31,0 & 37 & 23,9 & 3,43 & 1,24 \\
\hline $\begin{array}{l}\text { Turkish people are insensitive } \\
\text { towards protection of the } \\
\text { environment outside their homes. }\end{array}$ & 58 & 13,9 & $\begin{array}{l}37 \\
4\end{array}$ & 65 & $\begin{array}{r}41 \\
, 9\end{array}$ & $\begin{array}{c}8 \\
5,2\end{array}$ & 12 & 7,7 & 12 & 7,7 & 2,06 & 1,19 \\
\hline $\begin{array}{l}\text { Conscious consumption as well as } \\
\text { technology is necessary for } \\
\text { solution of environmental issues. }\end{array}$ & 104 & 12,2 & $\begin{array}{l}34 \\
, 4\end{array}$ & 67 & $\begin{array}{l}67 \\
, 1\end{array}$ & 42 & $\begin{array}{l}27 \\
, 1\end{array}$ & $\begin{array}{c}2 \\
1,3\end{array}$ & $\begin{array}{c}2 \\
1,3\end{array}$ & $\begin{array}{c}5 \\
3,2\end{array}$ & 1,46 & 0,86 \\
\hline $\begin{array}{l}\text { With their buying decisions, } \\
\text { consumers can individually } \\
\text { contribute to the efforts at } \\
\text { protecting the environment. }\end{array}$ & 76 & 10,0 & $\begin{array}{l}31 \\
, 1\end{array}$ & 49,0 & 6 & 6 & $\begin{array}{l}42 \\
, 6\end{array}$ & $\begin{array}{c}4 \\
2,6\end{array}$ & $\begin{array}{c}7 \\
4,5\end{array}$ & $\begin{array}{c}2 \\
1,3\end{array}$ & 1,66 & 0,83 \\
\hline
\end{tabular}




\begin{tabular}{|c|c|c|c|c|c|c|c|c|c|c|c|c|}
\hline $\begin{array}{l}\text { Business managers use } \\
\text { environmentalism for purposes of } \\
\text { advertisement only. }\end{array}$ & 43 & 27,7 & 75 & 48,4 & 26 & 16,8 & 4 & 2,6 & 7 & 4,5 & 2,07 & 0,97 \\
\hline $\begin{array}{l}\text { Businesses are responsible for } \\
\text { collecting their own waste. }\end{array}$ & 65 & 41,9 & 62 & 40,0 & 12 & 7,7 & 10 & 6,5 & 6 & 3,9 & 1,90 & 1,04 \\
\hline $\begin{array}{l}\text { Businesses should encourage } \\
\text { consumers regarding recollection } \\
\text { of solid waste (advertisements, } \\
\text { various gifts etc.). }\end{array}$ & 82 & 5 & $\begin{array}{l}2 \\
9\end{array}$ & 62 & $\begin{array}{l}40 \\
, 0\end{array}$ & 5 & $\begin{array}{l}3, \\
2\end{array}$ & 4 & 2,6 & $\begin{array}{c}2 \\
1,3\end{array}$ & 1,59 & 0,78 \\
\hline $\begin{array}{l}\text { It should not be a duty of a } \\
\text { municipality to collect solid waste. }\end{array}$ & 38 & 24,5 & 40 & 25,8 & 41 & 26,5 & 26 & 16,8 & 10 & 6,5 & 2,54 & 1,21 \\
\hline $\begin{array}{l}\text { The numbers of recycling boxes } \\
\text { on the streets of the city should be } \\
\text { increased. }\end{array}$ & 95 & 61,3 & 46 & 29,7 & 7 & 4,5 & 3 & 1,9 & 4 & 2,6 & 1,54 & 0,87 \\
\hline $\begin{array}{l}\text { Businesses are not sincere when } \\
\text { they emphasize that they are } \\
\text { environmentalists. }\end{array}$ & 53 & 34,2 & 62 & 40,0 & 29 & 18,7 & 5 & 3,2 & 6 & 3,9 & 2,02 & 1,00 \\
\hline
\end{tabular}

1: I absolutely agree.....5: I absolutely do not agree.

According to Table 5, 46.5 of the students do not agree with the statement that "Progress is more important than the environment for developing countries like Turkey." The students do not agree with the statement that "Making investments to solve environmental issues is luxurious for Turkey" (71.6\%; Average: 3.89). In the opinions of $54.9 \%$, increasing Turkey's production of electricity is more important than environmental pollution (Average: 3.43). $79.3 \%$ think that Turkish people are insensitive towards protection of the environment outside their homes (Average: 2.06). They support the statement that "conscious consumption as well as technology is necessary for solution of environmental issues" by $94.2 \%$. According to $91.6 \%$, "with their buying decisions, consumers can individually contribute to the efforts at protecting the environment" (Average: 1.66). They believe that "business managers use environmentalism for purposes of advertisement only" (76.1\%; Average: 2.07). According to $81.9 \%$, businesses are responsible for collecting their own waste (Average: 1.90). They agree with the statement that "businesses should encourage consumers regarding recollection of solid waste" (92.9\%; Average: 1.59). According to $50.3 \%$, it should not be a duty of only a municipality to collect solid waste (Average: 2.54). The rate of those who support the statement that "the numbers of recycling boxes on the streets of the city should be increased" is $91 \%$ (Average: 1.54). According to $74.2 \%$, businesses are not sincere when they emphasize that they are environmentalists (Average: 2.02). 


\section{Results}

The understanding of classical marketing which views marketing as equivalent to sales has over time given way first to the understanding of modern marketing and then to the understanding of social marketing. The tendency today is to carry out activities of marketing within the triangle of firm-society-consumer and generate the maximum utility for all parties. The fact that environmental awareness has been gaining importance in recent years has caused the "green" trend to influence marketing. Developments such as using less packaging and reusing used packaging, assessing the environmental properties of products and preferring products with natural content have drawn the attention of business top managers, especially marketing managers, towards these issues. Important developments are being observed in this field in our country. "The Legislation on Control of Solid Waste" has come into force on March 12, 1991. In this way, it is anticipated that disposed containers will reenter into production, be recycled or be controlled not to be harmful to the environment. ÇEVKO (The Foundation for Protection of Nature and Evaluation of Packaging Waste), which was established by different companies, aims to help collect, classify and bring back into the economy the packaging waste of consumer products. It is difficult to say, however, that companies in our country are inclined for green marketing. While green messages appear frequently in advertisements, it is obvious that these messages are used without any standards.

There is no control over products offered in the market as green products in Turkey. An autonomous organization needs to be formed in order to investigate whether these products really are not harmful to the environment. There are two important institutions in the US which give certificates of environmental friendliness. These organizations, named The Green Cross and The Green Seal, work to respond to the expectations of both consumers and producers. For example, firms which produce paper products are compelled to do a certain amount of reforestation for using forests. It is inevitable for Turkey, which makes plans to enter the EU, to manufacture products compatible with the environmental standards of the countries in the union so that she can trade with them. Otherwise, the Turkish industry and exports may halt significantly and serious losses of income from exports may ensue. Issuing heavy taxes under the name of "green tax" on plastic drink bottles, packages and other products with any kind of package, paper or glass may encourage businesses which manufacture these kinds of goods to switch to environmentally friendly methods of production in Turkey. While the highly young population of the country is an indicator that 
the number of green products will increase in time, it is important not only for marketers but also for protection of nature that young people place importance on the environment. The expectation in the 1990's that practices of green marketing would lead to a revolution in the environmental approaches of businesses did not come true due to the claims that the performances of green products were insufficient, to misinformation and to inadequate legal support. The skepticism on the part of consumers regarding green products caused many green products to be taken off the market. In order to prevent this situation, some countries intervened and regulated the conditions of competition in marketing.

A product or technology which is recommended for not being harmful to the environment may sometimes be found,as environmental engineering advances, to be harmful to the environment. For this reason, businesses which adopt these activities and announce them to their customers may strand when these activities are found to be not useful but harmful to the environment. Businesses have assumed that new technologies used to manufacture green products would provide a cost advantage in inputs. The obligation to undertake changes in products and processes of production in order for the green understanding to show on practice, and its additional costs have distanced some businesses from the attempt. Legal regulations also cause additional costs for businesses. That a product is green is not enough for consumer demand. Even environmentally sensitive consumers consider many different criteria for green products.

Cultural differences and different levels of economic development diversify individuals' priorities. While an individual's priority is to meet his or her basic needs in an underdeveloped country, environmental sensitivity becomes more important in a developed country. Legal regulations, too, vary by country. As a consequence, environmental issues are among the most important problems today. Environmental issues are vital problems which concern the existence of nature and thus the existence of humankind directly. It is extremely important to develop environmentally sensitive approaches of management and forms of production for a sustainable economy, for a sustainable business administration and for sustainable marketing. Organizations and businesses consist of people. Thus, if individuals become more conscious regarding the environment and more sensitive towards environmental issues, then both organizations and businesses will become more sensitive towards the natural environment. 
After all, it is critical in terms of environmentalism and green marketing that a person is sensitive towards environmental problems and bears social responsibility. Environmentally sensitive businesses need to address these processes as a whole. A deficiency in any step may bring the entire process to a halt and make it harder to reach goals and purposes. Businesses design and implement their activities according to individuals' demands. If individuals become more conscious regarding the environment, display their sensitivity and express their demands, then environmental gains will increase. Schools of Economic and Administrative Sciences, especially Departments of Economics, are where students who are expected to hold active offices in businesses in the future are educated. If students in these departments become more conscious, then they will accordingly transform the businesses where they work. The thoughts of the students of Atatürk University, Faculty of Communication.concerning the environment and green marketing are generally hopeful. In general, the behaviors of the majority concerning green marketing are found to be not continuous and systemic and to appear from time to time. In this regard, it is necessary for students, who are candidates for nomination for manager, to become more conscious. 


\section{References}

Chamorro, A.,Tomas M. (2006). Green Marketing Philosophy: A Study of Spanish Firms withEco-labels, CorporateSocialResponsibilityandEnvironmental Management, Vol.13, N.1:11-24.

Demirbaş, M. (1999). Yeşil Pazarlama (Green Marketing) ve Tüketicinin Yeşil Pazarlamaya Yaklaşımı, Basılmamış Yüksek Lisans Tezi, Gazi Üniversitesi Sosyal Bilimler Enstitüsü, Ankara. 35.

Durali, H. (2002). Pazarlama-Çevre ilişkisi ve Anadolu Üniversitesi Öğrencilerinin Tüketici Olarak Çevreyle İlgili Tutum ve Davranışlarını Belirlemeye Yönelik Bir Araştırma, Basılmamış Yüksek Lisans Tezi, Osmangazi Üniversitesi, Sosyal Bilimler Enstitüsü, Eskişehir. 30.

Erbaşlar, G. (2007). Yeşil Pazarlama, Paradoks Ekonomi, Sosyoloji ve Politika Dergisi, www.paradoks.org, ISSN 1305-7979, Y11:3, Say1:1.25.

Grove, S. (1996). GoingGreen in the Service SectorSocialResponsibilityIssues, ImplicationsandImplementation", EuropeanJournal of Marketing, Vol.30, N.5: 5666.

Jain, K.,Gurmeet K. (2004). Green Marketing: An AttitudinalandBehavioural Analysis of IndianConsumers, Global Business Review, Vol.5, N.2:187-205.

Langerak, F. (1998). ExploratoryResults on theAntecedentsandConsequences of Green Marketing, Journal of the Market ResearchSociety, http://proquest.umi.com.21.

Marangoz, M. (2003). Yeşil Pazarlama ve İşletmelerin Yeşil Pazarlama Anlayış ve Uygulamalarının Değerlendirilmesine Yönelik Bir Araştırma, Basılmamış Doktora Tezi, T.C. Dokuz Eylül Üniversitesi Sosyal Bilimler Enstitüsü, İzmir.44.

Moisander, J. (2007). MotivationalComplexity of GreenConsumerism,International Journal of Consumer Studies, 31:404-409.

Ottman, J.,Edwin R. Stafford, Cathy L. Hartman. (2006). AvoidingGreen Marketing Myopia, Environment, Vol.48, N.5:24-36.

Shamdasani, P.,Gloria O., Chon-L., Daleen R. (1993). ExploringGreenConsumers in an OrientalCulture: Role of Personaland Marketing MixFactors, Advances in Consumer Research, Vol.20: 488-493.

Soonthonsmai, V. (2001). PredictingIntentionandBehavior to PurchaseEnvironmentally Sound orGreenProductsAmongThaiConsumers: An Application of TheTheory of 
Reasoned Action, Doktora Tezi, TheWayneHuizengaGraduate School of Business andEntrepreneurship Nova Southeastern University.18. 